\title{
TARTU RADIOCARBON DATES III
}

\author{
J. M. PUNNING, A. LIIVA, and E. ILVES
}

Institute of Zoology and Botany, Academy of Sciences, Estonian SSR

In dating the samples reported here as well as in calculating their ages, the same equipment and method of processing and counting were used which were previously described in Tartu I and II.

TA-103. Akali

$6255 \pm 100$

4305 B.c.

Arboreal coal from hearth of settlement Akali, $4 \mathrm{~km} \mathrm{~S}$ of village Praaga on right bank of Akali R., Tartu Dist., Estonian SSR. Putative age of sample: 3rd millennium B.c. or older. Coll. 1966 by K. Jaanits, subm. by L. Jaanits, Hist. Inst., Acad. Sci. of Estonian SSR.

\section{TA-121. Byzovaya}

$18,320 \pm 280$ 16,370 B.c.

Bones of mammoth (Mammonteus primigenius Blumenbach) found near settlement Byzovaya, Pechorskij Dist., Komi ASSR. Sample depth, 1.5 to $20 \mathrm{~m}$. Probable age: Late Pleistocene (Ilves et al., 1968). Coll. 1964 by V. I. Kanivtsa, subm. by I. E. Kuzmina, Zool. Inst. Acad. Sci. of SSSR.

\section{TA-134. Naroch}

$$
10,100 \pm 95
$$

Wood remains from sec. on $S$ bank of Lake Naroch, Myadel'skij Dist., Byelorussian SSR. In abrasion terrace outcrop: grayish-yellow sand (fill), $100 \mathrm{~cm}$; sod-podzolic soil overlying sand with admixture of gravel, $70 \mathrm{~cm}$, eolian and lacustrine sands, $400 \mathrm{~cm}$, alluvial peat with interlayers of muddy sand, in places containing many wood fragments and intact tree trunks, 15 to $20 \mathrm{~cm}$, lacustrine sand with sparse inclusions of gravel and shingle. Visible thickness 80 to $100 \mathrm{~cm}$ (Voznyachuk and Punning, 1967). Silicon implements attributed by V. B. Bud'ko and M. M. Chernyavskij to end of Late Paleolithic or Early Mesolithic were found near outcrop in sand. According to V. A. Kaleshishtch, sample contains pollen of pine up to $94 \%$, birch $5 \%$, spruce $0.5 \%$, alder $0.5 \%$, and willow $1 \%$. Coll. 1966 and subm. by L. N. Voznyachuk, Byelorussian State Univ.

\section{TA-135. Naroch}

$$
\begin{gathered}
10,810 \pm 100 \\
\mathbf{8 8 6 0} \text { B.C. }
\end{gathered}
$$

Fragments of big tree trunk (according to $\mathrm{H}$. Paaves, Pinus silvestris) from outcrop where sample TA-134 was collected. Submerged alluvial peat formed in late Alleröd or on border of Alleröd and Dryas intervals, also corroborated by paleocarpological, palynological, and archaelogical data. 


\section{TA-136. Peedu}

Large wood fragments from inter-morainic stratum near town Elva on NW Otepää elev. in SE Estonia. Pollen analysis by E. Liivrand shows that when lake and swamp deposits accumulated alder $(\sim 50 \%)$ and fir ( 1 to $10 \%$ ) pollen, spruce and pine also played important role in ancient vegetation; pollen grains of white beech and elm were also detected (Punning et al., 1967). Palynologically, profile has some features similar to deposits at Karuküla (Serebryanny et al., 1968).

\section{TA-137. Loobu}

$13,970 \pm 115$ 12,020 B.c.

Bryales peat containing calcareous aleurite and subfossils on left bank of Loobu R., Rakvere Dist., Estonian SSR. Stratigraphy of outcrop from surface: well-decomposed peat, $110 \mathrm{~cm}$; lime sapropelite containing plant remains and shells, $45 \mathrm{~cm}$; Bryales peat with bluish-gray lime aleurite and subfossils, $9 \mathrm{~cm}$; Bryales peat slightly muddy with subfossils, $9 \mathrm{~cm}$; bluish-gray clay with plant remains in upper part, 177 $\mathrm{cm}$; gray stratified clay. Sample depth, 160 to $169 \mathrm{~cm}$. Pollen-analysis by R. Pirrus. Sample attributed to Pollen Zone IX (V. Post-Nilsson system). Coll. 1966 and subm. by R. Pirrus, Geol. Inst., Acad. Sci. of Estonian SSR.

\section{TA-138. Loobu}

$14,725 \pm 260$

Bryales peat with lime aleurite and subfossils coll. at depth 170 to $178 \mathrm{~cm}$. Sample is referred to Pollen Zone X (see TA-137). Comment: greater sample age is probably due to incorporation of carbonates from ancient limestone dissolved in water.

\section{Vaskrääma series}

Submerged organogenous deposits $0.5 \mathrm{~km} \mathrm{~W}$ of Vaskrääma RR Sta., on beach of Pärnu Bay, SW Estonia. Stratigraphy of sec.: humified sand 0 to $25 \mathrm{~cm}$; limonitic sand 25 to $55 \mathrm{~cm}$, sand containing gravel 130 to $177 \mathrm{~cm}$; clay. Upper part of organogenous layer submerged by Littorina deposits is composed of lagoon sapropels; lower part is made up of woody peat. In upper art of organogenous layer brackish water diatoms are found (Campylodiscus clypeus Ehr.). Pollen analysis by H. Kessel, Geol. Inst., Acad. Sci. of Estonian SSR. Coll. 1966 by J. M. Punning, subm. by H. Kajak, State Production Geol. Comm. of Estonian SSR, later referred to as Geol. Comm.

\section{TA-139. Vaskrääma}

$6870 \pm 110$

Depth of sample, 135 to $140 \mathrm{~cm}$. Sample attributed to Pollen Zone VI (V. Post-Nilsson system). 
TA-140. Vaskrääma

$6975 \pm 110$

5025 в.c.

Sample at depth 145 to $150 \mathrm{~cm}$ is referred to Pollen Zone VI (V. Post-Nilsson system). From this level downward brackish-water diatoms are found in sapropels.

TA-141. Vaskrääma

$7580 \pm 170$ 5630 в.c.

Sample at depth 165 to $170 \mathrm{~cm}$ is attributed to Pollen Zone VII (V. Post-Nilsson system).

\section{TA-154. Kostenki XII}

$20,900 \pm 390$

18,950 в.C.

Bones of horse (Equus caballus L.) from Paleolithic settlement in Kostenki Dist. on right bank of Don R., S of town Voronezh. Sample depth, 2.0 to $2.5 \mathrm{~m}$. Probable age: Late Paleolithic (Ilves et al., 1968). Coll. 1964 by A. N. Rogalyeva, subm. by I. V. Kuzmina.

\section{TA-156. Arashu}

$$
1060 \pm 60
$$

A.D. 890

Wood remains from settlement on Lake Arashu, Cesis Dist., Latvian SSR, $7 \mathrm{~km} \mathrm{~S}$ of town Cesis. Depth, $75 \mathrm{~cm}$. Coll. 1966 and subm. by J. F. Apals, Hist. Inst. Acad. Sci. of Latvian SSR.

\section{TA-157. Vigala}

$7375 \pm 170$

5425 B.c.

Brown reed peat from deposits of Littorina transgression near Vigala RR Sta., Rapla Dist., Estonian SSR. Thickness of organogenous layer, $35 \mathrm{~cm}$. Underlying layer: clayey aleurite with plant remains: overlying layer: fine-grained-to-aleurite sand with plant remains. Sample depth, 165 to $175 \mathrm{~cm}$. Coll. 1966 and subm. by H. Stumbur, Geol. Comm.

TA-159. Rannapungerja

$910 \pm 200$

Wood remains (oak) from bank of Rannapungerja R., Mustvee Dist., Estonian SSR. Depth, $300 \mathrm{~cm}$. Sample underlies alluvial sands. Pollen analysis by R. Pirrus indicates Pollen Zone I b (V. Post-Nilsson system). Coll. 1966 and subm. by E. Rähni, Geol. Inst.

\section{TA-160. Smorgoni}

A.D. 1280

$\mathbf{6 7 0} \pm 50$

Well-preserved fragment of oak from quarry near Smorgoni Hydromechanized Gravel Plant, $130 \mathrm{~km} \mathrm{NW}$ of Minsk, Byelorussian SSR, floodland of Viliya R. Many bones of mammals, (musk ox, bison, deer, etc.) were found in these quarries. Depth of oak trunks, 400 to $600 \mathrm{~cm}$. Coll. 1966 and subm. by L. N. Voznyachuk.

\section{TA-161. Smorgoni}

$1045 \pm 60$

Fumed oak from quarry near Smorgoni Hydromechanized Gravel Plant (see TA-160). 


\section{TA-162. Abava}

Wood remains from 1st riparian terrace of Abava R. near Sabile, Jelgava Dist., Latvian SSR. Stratigraphy of deposits from surface finegrained, light-gray sand, $130 \mathrm{~cm}$. Well-decomposed sedge and Bryales peat with wood remains 130 to $100 \mathrm{~cm}$; fine-grained gray sand 160 to 180 $\mathrm{cm}$; slightly decomposed Carex-Bryales peat with wood remains 180 to $275 \mathrm{~cm}$; bluish-gray sandy loam with interlayers of moss 275 to $315 \mathrm{~cm}$. Sample taken from upper peat layer and pollen-analyzed by V. Stelle. Putative age: Pre-Boreal or Boreal. Coll. 1966 and subm. by V. Stelle, Geol. Inst. of Latvian SSR.

\section{TA-163. Abava}

Wood remains from lower peat layer of riparian terrace of Abava R. (see TA-162). Probable age: Late Dryas. Coll. 1966 and subm. by V. Stelle.

\section{TA-175. Sindi}

$9300 \pm 75$ 7350 B.c.

Humified peat from quarry wall near RR bridge at Sindi on right bank of Pärnu R., Pärnu Dist., Estonian SSR. Depth, 230 to $233 \mathrm{~cm}$. Pollen analysis by $\mathrm{H}$. Kessel, Geol. Inst., attributes sample to Pollen Zone IX (V. Post-Nilsson system). Coll. 1967 and subm. by H. Kajak.

\section{TA-176. Sindi}

Wood remains from layer of humified clayey sand taken from quarry wall near RR bridge at Sindi (see TA-175). Depth, 315 to $325 \mathrm{~cm}$. Layer contains deer bones and remains of fish skeletons. Sample is referred to Pollen Zone IX (V. Post-Nilsson system). Coll. 1967 and subm. by H. Kajak.

\section{TA-177. Raunis}

$13,250 \pm 160$

Remains of Sphagnum and green mosses from exposure near CesisVeselava Rd., $100 \mathrm{~m}$ below road bridge on right bank of Raunis R., Latvian SSR. Stratigraphy of exposure: soil 0 to $30 \mathrm{~cm}$; sandy stratum with lenses of loam, 30 to $200 \mathrm{~cm}$; dark brown moraine with prevailing loamy substance; rubbly fraction with carbonaceous rocks predominating, 200 to $230 \mathrm{~cm}$; stratified organic remains, 230 to $285 \mathrm{~cm}$; moraine. Strata where sample was taken at depth 260 to $275 \mathrm{~cm}$ is composed of aleurite with well-preserved remains of Sphagnum and green mosses. Dating of these plant remains at Vernadski Inst. of Geochem. and Analytic Chem. yielded age 13,390 \pm 500 yr. (Mo-296, Vinogradov, et al., 1963.) Coll. 1967 and subm. by J. M. Punning, Geol. Comm. 


\section{TA-180A. Sinialliku}

A.D. 1085

$865 \pm 50$

Charcoal from ancient stronghold at Sinialliku $0.5 \mathrm{~km}$ SE of Sinialliku RR Sta., Viljandi Dist., Estonian SSR. Sample at depth $130 \mathrm{~cm}$ from soil containing charcoal. Probable age: end of 12th or beginning of 13th century. Coll. 1967 and subm. by J. Selirand, Hist. Inst., Acad. Sci. of Estonian SSR.

\section{TA-180B. Sinialliku}

Same sample as TA-180A, but counting material was synthesized by using vanadium-oxide as catalyst.

\section{TA--181. Kärla}

$7085 \pm 80$

Reed peat underlying Littorina deposits at locality Kärla, Is. Saaremaa, Estonian SSR. Thickness of organogenous layer, $36 \mathrm{~cm}$. Depth (with reference to organogenous layer), 0 to $3 \mathrm{~cm}$. Pollen analysis by H. Kessel attributes sample to Pollen Zone VII (V. Post-Nilsson system). Coll. 1967 by J. M. Punning, subm. by G. Elterman, Geol. Comm.

\section{TA-182. Kärla}

$7820 \pm 80$

$\mathbf{5 8 7 0}$ B.C.

Wood peat at locality Kärla (See TA-181). Depth, with reference to organogenous layer, 30 to $33 \mathrm{~cm}$. Pollen analysis indicates Pollen Zone VII (V. Post-Nilsson system). Coll. 1967 by J. M. Punning, subm. by G. Elterman.

\section{TA-183. Seliste}

Well-decomposed muddy peat underlying Littorina deposits, Pärnu Dist., Estonian SSR. Depth of organogenous deposits, 265 to $317 \mathrm{~cm}$. Sample at depth 3 to $8 \mathrm{~cm}$ (with reference to organogenous layer). Coll. 1967 and subm. by H. Kajak.

Date lists:

Tartu I Liiva, Ilves, and Punning, 1966

Tartu II Punning, Ilves, and Liiva, 1968

Ilves, E., Punning, J. M., and Liiva, A., 1968, Dating of bone samples by the radiocarbon method: Proc. of Acad. Sci., Estonian SSR, in press.

Punning, J. M., Ilves, E., and Liiva, A., 1968, Tartu radiocarbon dates II, Radiocarbon, v. 10, no. 1, p. 124-130.

Punning, J. M., Raukas, A. V., and Serebryanny, L. R., 1967, Geochronology of the latest glaciation of the Russian Plain in the light of modern radiocarbon datings of lake and bog fossil deposits of the Baltic Region: Materialy II simposiuma po istorii ozyer severo-zapada SSR Minsk.

Vinogradov, A. P., Devirts, A.L., Dobkina, E. I., and Markova, N. G., 1963, Determination of absolute age by $\mathrm{C}^{14}$ : Soobshcheniya 4, Geochimiva, no. 9.

Voznyachuk, L. N. and Punning, J. M., 1967, Find of Alleröd deposits on the banks of Lake Naroch and some peculiarities of the history of the Late and Post-Pleistocene: Materialy II simposiuma po istorii ozyer severo-zapada SSR, Minsk.

Serebryanny, L., Raukas, A., and Punning, J. M., Fragments of the natural history of the Russian Plain during the Late Pleistocene with special reference to radiocarbon datings of fossil organic matter from the Baltic Region: Publ. House "Baltica," Vilnius, in press. 